ENTREPRENEURSHIP AND SUSTAINABILITY ISSUES

ISSN 2345-0282 (online) http://jssidoi.org/jesi/ 2020 Volume 8 Number 1 (September)

http://doi.org/10.9770/jesi.2020.8.1(35)

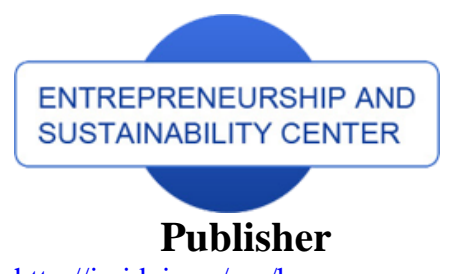

http://jssidoi.org/esc/home

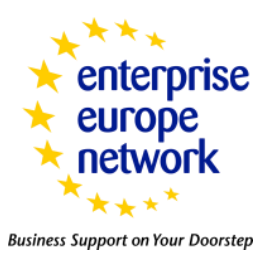

CASPA

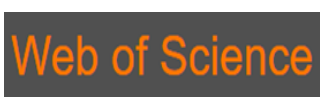

1 Clarivate

\title{
TRANSNATIONAL CORPORATIONS IN PRIVATE INTERNATIONAL LAW: DO KAZAKHSTAN AND RUSSIA HAVE THE POTENTIAL TO TAKE THE LEAD?
}

\author{
Aigul Nukusheva ${ }^{1}$, Gulzhazira Ilyassova ${ }^{2}$, Larisa Kudryavtseva ${ }^{3}$, Zhanna Shayakhmetova ${ }^{4}$, \\ Amina Jantassova ${ }^{5}$, Larisa Popova ${ }^{6}$ \\ 1,2 Buketov Karaganda State University, Karaganda, The Republic of Kazakhstan \\ ${ }^{3,6}$ FGBOU VO Kuban State Agrarian University named after I.T. Trubilin, Krasnodar, Russian Federation \\ ${ }^{4}$ Atyrau State University after Kh. Dosmukhamedov, The Republic of Kazakhstan \\ ${ }^{5}$ Karaganda economic university, Karaganda, The Republic of Kazakhstan \\ E-mails: ${ }^{1}$ aigulnukusheva4@gmail.com ; ${ }^{2}$ ilyassovagul@rambler.ru ; ${ }^{3}$ kudryavtsevalar@ rambler.ru ; \\ ${ }^{4}$ jan68@inbox.ru ; ${ }^{5}$ jantassovaami@ rambler.ru ; ${ }^{6}$ popovalari1@ rambler.ru
}

Received 15 February 2020; accepted 25 June 2020; published 30 September 2020

\begin{abstract}
The aim of this paper is to determine role of transnational corporations (TNCs) in a struggle of Kazakhstan and Russia towards leadership. Concepts and hypotheses from available literature on economic globalization, TNCs, their impact on national economies, and innovation-driven development were analyzed. Most Kazakh corporations have low nominal capitals and hold shares, total value of which does not meet minimum requirements for global competition. Kazakhstan and Russia fail to secure mutual benefit of participants in investment relationship, as well as national interests. Foreign investors professionally utilize all the gaps and weaknesses that can be found in the investment law. In this regard, TNCs are the most prepared, as they have substantial resources to create favorable conditions for market presence.
\end{abstract}

Keywords: transnational corporation; international investing; foreign direct investment; capital concentration; cross-border penetration; mergers and acquisitions; investment policy

Reference to this paper should be made as follows: Nukusheva, A., Ilyassova, G., Kudryavtseva, L., Shayakhmetova, Zh., Jantassova, A., Popova, L. 2020. Transnational corporations in private international law: do Kazakhstan and Russia have the potential to take the lead? Entrepreneurship and Sustainability Issues, 8(1), 496-512. http://doi.org/10.9770/jesi.2020.8.1(35)

JEL Classifications: K33; P33.

Additional disciplines: law

\section{Introduction}

Under current conditions of international investing, transnational corporations are among the main participants in investment relationships. The term "Transnational Corporation" (TNC) emerged as a compromise during negotiations on the UN mandate restricting international monopolies in developing countries (Sagafi-Nejad and Belfield ${ }^{2014)}$. The United Nations use it to designate an organization that, regardless of its type of ownership 


\section{ENTREPRENEURSHIP AND SUSTAINABILITY ISSUES}

ISSN 2345-0282 (online) http://jssidoi.org/jesi/ 2020 Volume 8 Number 1 (September) http://doi.org/10.9770/jesi.2020.8.1(35)

(private or public), operates in two or more countries in accordance with a decision-making system that allows for coordinated policy and a common strategy. Transnational corporations operate their own facilities outside their countries of origin and without a centralized system to allocate resources, technology and to assign responsibilities (Khasbulatov ${ }^{2015)}$. The United Nations Conference on Trade and Development (UNCTAD) expands the definition with parent companies and their foreign affiliates. A transnational corporation refers to a corporation that carries out production and (or) marketing activities as long as these activities take place outside a parent country. TNCs have a great impact on host country's economy. Cross-border operations constitute a significant portion of foreign trade turnover even in large Western countries. Corporate globalization allows companies to transfer substantial resources from country to country for their own benefit. TNCs effect on national economy depends on economic power of subjects engaged in business relationship and on a status of companies established in a host country (Tauris 2011). TNC is a monopolist that undertakes foreign direct investments (FDI), operates outside its country of origin, has multiple affiliates and ventures, and influences host country's economy. It is a driving force behind crucial processes in world economy. A transnational corporation defines dynamics, structure, and competitiveness of goods and services in the global market and controls international capital movements. Because of their production and financial capabilities, TNCs engross knowledge-intensive units thereby contributing to technological progress in production (Sacher and Cooney 2018).

There are also other criteria for classifying a particular company as transnational. Among them, there is an annual income of over $\$ 100$ million. Based on international investment experience, other criteria may include:

1. International coverage (countries in which a company operates, from 2 to 6 countries minimum);

2. Capacity (countries in which company's production facilities are located);

3. Company's size;

4. High proportion of voting shares (25\% or more). This minimum ensures company's control over economic activities of a foreign enterprise and represents FDI;

5. Multinational staff.

TNCs have a constantly growing role in international production, trade, finance and other areas. The world economic system comprises about 100 transnational corporations that consolidate more or less unlimited economic power and secure about a third of all foreign investments (United Nations Conference 2011).

Today, there are many TNCs scattering across developing and developed countries. It is remarkable that both face the same problems, which are associated with a fast-economic growth, such as:

1. FDI policy liberalization, which opens up new opportunities for corporate development;

2. Advancements in the field of transport, communication and information, and technologies that create opportunities for managing integrated industrial relations with foreign affiliates;

3. Increasing competition between organizations, which encourages them to take advantage of new opportunities.

Current roles of transnational corporations in global economy are as follows:

- $\quad$ TNCs control approximately two-thirds of the world trade and 40\% thereof takes place within TNCs. This means that trade occurs not at market but at transfer prices, which form under a long-term policy of a parent corporation;

- $\quad$ TNCs account for about a half of global industrial production;

- $\quad$ TNCs employ approximately $10 \%$ of non-agricultural workers (almost $60 \%$ of employers are parent companies);

- $\quad$ TNCs control approximately four-fifth of all patents, licenses and know-how existing in the world and thus have a significant role in global R\&D (Tomasic ${ }^{2017}$.

From the legal point of view, one of the most distinguishing features of transnational corporations is an inconsistency between their economic content, their economic substance and their legal form. Legal construct of TNC itself implies a presence of multiple entities (parent company and foreign affiliates) with their own interests (Matsuzawa 2019). It is rather difficult to designate nationality of transnational corporations because their parent 


\section{ENTREPRENEURSHIP AND SUSTAINABILITY ISSUES}

ISSN 2345-0282 (online) http://jssidoi.org/jesi/

2020 Volume 8 Number 1 (September)

http://doi.org/10.9770/jesi.2020.8.1(35)

companies and subsidiaries may be established legitimately in other countries and have different legal identities. This suggests that the main characteristics of a transnational corporation that allow illuminating its legal side are: 1) legal multiplicity; 2) international focus; and 3) ability to affect economy of a host country.

TNCs are often known as multinational corporations or global companies but there is an ultimate difference between these three types of organization. Global companies have a marketing campaign that does not adapt to local norms, whereas multinational corporations adapt their marketing messaging to fit each culture group (Preston and Windsor 2013). Genuinely, the higher degree of cross-border penetration, the deeper integration of TNCs into a national market. Therefore, TNCs not only own income-gathering assets in other countries but also produce consistent services or products (sometimes with an optional local feature added to the standard range). Although TNCs may be considered international for their operation in a cross-border environment, they are neither importers nor exporters alone.

Since the declaration of independence, the Republic of Kazakhstan and the Russian Federation have been maintaining their focus on economic development and population well-being. At the same time, a full support and protection of foreign investments remain among the most important directions of national economic policy (Nukusheva and Kudryavtseva 2017).

From this perspective, actions to achieve a deeper penetration by TNCs into a market of a host country become a hot topic.

The main stages of this penetration are:

1. Market Presence

The company may either have a permanent office (representative office, branch office, subsidiary, joint venture) in the host country or produce large-scale services besides trade (engineering, consulting) without having such an office in the area;

2. Engagement in Production

Even if the company engages in production at the insignificant level, this commitment marks a new depth of penetration;

3. Dedication to $R \& D$

Companies, especially representatives of new industries, set a high value to the potential of human resources and $\mathrm{R} \& \mathrm{D}$ in the host country. For hosts, such an interaction is a direct route to foreign experience in the field of technology (Berberoglu 2016).

Variously termed representative offices and branch offices, and subsidiaries, and joint ventures are mentioned in same contexts. The alternative use of these words is a reason for legal misinterpretation when it comes to market penetration by TNCs.

Subsidiaries or legal entity's set-apart subdivisions, performing all its functions or a part thereof (including functions of representation), appear due to production establishment and expansion (Civil Code of the Republic of Kazakhstan 1994). Representative offices form another case. Difference between a representative office and a joint venture is even more pronounced. Therefore, one my consider TNCs penetrating the economy of a host country through two stages: 1) market presence (implies international business activity, including through representative offices); and 2) production establishment (opening of a branch office, a subsidiary or a joint venture). Each stage may provide for both deal-specific actions and a whole range of legal actions to create a legal entity. It is obvious that the first stage is an initial step to gather information necessary for making a decision on deepening the penetration (on establishing production in the particular area). In terms of the third "main" stage of penetration, the company that dedicates $R \& D$ activities to different national markets does not deepen its penetration. In fact, dedication to $R \& D$ is likely to be a sign of engagement in production because $R \& D$ centers cannot be launched apart from production units. 


\section{ENTREPRENEURSHIP AND SUSTAINABILITY ISSUES}

ISSN 2345-0282 (online) http://jssidoi.org/jesi/

2020 Volume 8 Number 1 (September)

http://doi.org/10.9770/jesi.2020.8.1(35)

In the global context, transnational corporations have an effect on innovation and technology as powerful as on economy. In 2007, 1000 EU companies and 1000 non-EU companies invested a total of $€ 372$ billion in R\&D or about $80 \%$ of global R\&D investment. In the US, the share of TNCs in R\&D reached $74 \%$ (Kordos and Vojtovic, 2016). In other words, TNCs use available resources of other countries to gain a competitive advantage. In recent decades, enterprises make a significant contribution to technology development. TNCs spend on R\&D more compared to national governments. Thus, expenditures on R\&D in Canada amounted to $\$ 7.2$ billion in 1980s or $1.3 \%$ of GNP, whereas six TNCs allocated $\$ 2.1$ billion for these purposes and there were more of transnational investors.

Small developed countries rely on technology in their competitive struggle and thus spend on R\&D more. For example, Sweden spends $\$ 5.5$ billion or $2.9 \%$ of GNP. Switzerland allocates less compared to TNCs: government expenditures amount to $\$ 3.9$ billion or $2.9 \%$ of GNP, while transnational companies allocate $\$ 4.4$ billion or $5.9 \%$ of their sales (Henderson 2014).

The 2016 Global R\&D Funding Forecast foresaw the increase in global R\&D investments by 3.5\% in 2016 to a total of $\$ 1.948$ trillion for more than 110 countries that had significant R\&D investments (more than $\$ 100$ million) at the time. As in previous years, Asian countries (including China, Japan, India and South Korea) account for more than $40 \%$ of all global R\&D investments, with North American investments now less than 30\% and European R\&D only slightly more than 20\% (2016 Global R\&D Funding Forecast 2016).

R\&D undertakings in the world focus on: 1) adapting goods and services produced by TNCs to local norms; 2) creating new products to meet local demands; 3 ) optimizing company's R\&D through the involvement of foreign affiliates; and 4) monitoring achievements for competitive advantages. Corporations with most ambitions set additional goals - to shape a global corporate culture (IBM) and to contribute to global science (Sony).

On the UNCTAD's transnationality index in 2002, Russia reached only $19 \%$, which is less compared to indicators of the neighboring countries (Estonia had 39\%, Moldova - 30\%, Lithuania - 23\%) (Jones and Wren 2016). Russia found its place among the top holders of FDI stocks in 2004 with a total equity capital of $\$ 98.444$ billion. Poland, Hungary, and the Czech Republic rose their inflow of FDI to $\$ 60$ billion. The Republic of Kazakhstan lags behind with $\$ 22.399$ billion, which still allows the country to occupy a second place among the CIS and Baltic countries. Kazakhstan is a recipient of higher investments compared to Central Asian countries (inflows into: Turkmenistan reach $\$ 1.464$ billion; Uzbekistan - \$1.057 billion; Kyrgyzstan - $\$ 568$ billion; Tajikistan $\$ 495$ billion). Another evidence on favorable investment regime in Kazakhstan is its consideration by the World Bank as one of the top 20 most attractive countries for investment. For countries in transition, FDI inflows decreased by $54 \%$ due to conflicts and a decline in commodity prices (Khasbulatov 2015).

This study aims to determine the role of TNCs in the struggle of Kazakhstan and Russia towards leadership. The purpose of the study is to identify the legal specifics of TNCs in the markets of Russia and Kazakhstan. The research tasks are as follows:

- assessment of penetration of TNCs in the markets of Russia and Kazakhstan;

- analysis of interaction of TNCs with infrastructure elements of the economies of Russia and Kazakhstan;

- systematization of examples of conflict situations' legal resolution between TNCs and local companies;

- finding the most vulnerable areas of local market regulation;

- outlining judicial experience of Russia and Kazakhstan in procedural cases involving TNCs.

TNCs remain among the factors of markets' significant transformation. Therefore, it is especially important to monitor the state of legal relations between TNCs and the host state, since such relations directly determine medium-term macroeconomic perspective of the local market. Russia and Kazakhstan, as developing countries with a fairly high level of purchasing power, are of particular interest to transnational corporations. These 
countries, due to imperfection of existing regulatory frameworks, can become whether a zone for rapid trade and industrial growth or a risk zone for structural crises. The said directly affects sustainability of socio-economic development of the region and thus determines relevance and importance of the current study.

This article is structured as follows. Section 1 provides the description and definition of TNC as a notion together with characteristics thereof, presents an overview of literature on TNCs both globally and with relation to Kazakhstan and Russia, defines actual questions and tasks of the study. Section 2 contains sources and methods used to analyze collected data together with the scheme of the research. The results of the study together with discussion thereof are presented in Section 3. Conclusions and recommendations of the research are provided in Section 4, and, finally, Section 5 contains study limitations.

\section{Methodology}

Theoretical and methodological framework includes concepts and hypotheses from available literature on economic globalization, TNCs, their impact on national economies, and innovation-driven development.

All speculations and conclusions are justified using a systematic approach and specific methods, such as synthesis, historical-logical analysis, inductive-deductive analysis, structural-functional analysis, and comparative analysis.

The following sources were used to collect data for the purposes of this research:

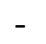

$-$

Development;



$-$

$-$

$-$ previous studies (relevant references are indicated for each study in the text);

World Investment Reports of the United Nations Conference on Trade and

Civil Code of the Republic of Kazakhstan (RK Civil Code);

Pig Books of Citizens Against Government Waste; Speeches of the President of the Republic of Kazakhstan; Speeches of the Prime Minister of the Republic of Kazakhstan.

Data and information were used for the purposes of this study, as follows:

$-$

$-$

$-$

$-$ major investors;

- $\quad$ figures and data of cross-border M\&A deals, including strategic alliances;

- $\quad$ figures and information on TNC-related court proceedings and decisions;

- $\quad$ other data and information analyzed for the study purpose.

figures and data of TNCs operating in Kazakhstan;

figures and data on TNCs operating globally and on country level;

figures of FDI, return on foreign investment on global and country level;

figures and data reflecting TNCs' influence in the USA;

US and Canada tax incentives;

Kazakhstan governmental incentives;

information on agreements signed by Kazakhstan on implementation of projects with

The scheme of the research is given in Figure 1. 


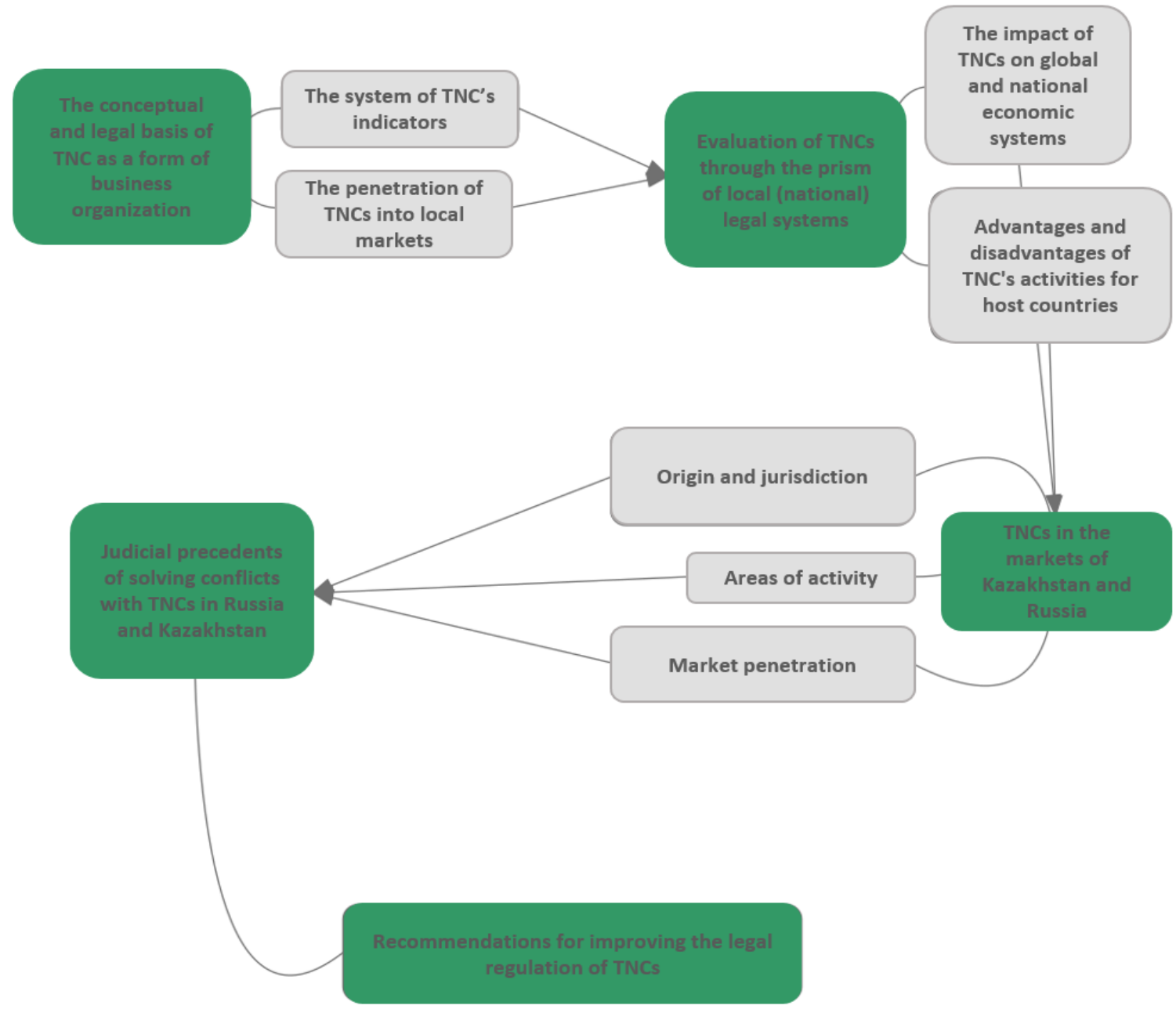

Figure 1. The scheme of the research

As shown in Figure 1, the research has five main stages (colored in green). First, TNC as form of business organization was examined from conceptual and legal points of view. Second, TNCs were evaluated in the view of local markets' legislation, including that of Kazakhstan and Russia. Third, various aspects of TNC operations on local markets were surveyed. Fourth, TNC-related legal proceeding held in Kazakhstan and Russia to resolve conflicts were analyzed. Based on legal precedents, recommendations of improving TNC regulation were developed as the fifth and final stage of the research. As intermediate stages, TNC indicators, markets penetration, impact on global and national economies, advantages and disadvantages for host countries, as well as TNCs' origin, jurisdiction and areas of activity were also investigated in course of the survey.

\section{Results and Discussion}

Today, there are about 40 thousand TNCs, with about 180 branch offices in 150 countries. By the beginning of the 21st century, the world's 500 largest TNCs have reached dominant market presence, accounting for $61 \%$ of global GDP. They control at least $70 \%$ of world trade and sell $80 \%$ of electronics and chemical products, $95 \%$ of medication, and $76 \%$ of engineering goods (Mudacumura et al. 2017). Among them, 100 TNCs control \$14 trillion in assets or one-third of global FDI (Perrone 2018). 


\section{ENTREPRENEURSHIP AND SUSTAINABILITY ISSUES}

ISSN 2345-0282 (online) http://jssidoi.org/jesi/ 2020 Volume 8 Number 1 (September) http://doi.org/10.9770/jesi.2020.8.1(35)

There are about 30 projects with TNC participation in Kazakhstan and companies like Danone, Lotte Group, BTM, and Coca-Cola even opened their production facilities there. Companies like Samsung, LG Electronics, General Electric, Volkswagen etc. have also opened their representative offices and production facilities but mostly for local development support through different initiatives and job creation, rather than for product nationalization (Motohashi ${ }^{2015)}$. In Kazakhstan, the largest TNCs are particularly active in an oil industry. In 1992, the Republic of Kazakhstan and Agip (Italy) and British Gas (the UK) companies signed an agreement on development of the Karachaganak oil and gas field. A year later was a starting point of cooperation between Kazakhstan and American oil companies when the contract was signed with Chevron Corporation for a period of 40 years (Stopford 2011).

The following are among the largest oil companies successfully operating in Kazakhstan today:

1. European companies:

British Gas (the UK);

Eni. (Italy);

Total SA (France);

Royal Dutch Shell (Germany);

Repsol YPF (Spain);

OMV Petrom S.A. (Romania);

Maersk Oil (Denmark);

2. US companies:

ExxonMobil;

ConocoPhillips;

3. Russian companies:

Lukoil and Rosneft;

4. Asian companies:

China National Petroleum Corporation (China);

Mittal Investments (India);

ONGC Videsh Ltd (India);

Kazakhturkmunai (Turkmenistan).

According to the 2018 World Investment Report, FDI flows to transition economies declined by $27 \%$, to $\$ 47$ billion, the second lowest level since 2005. This decline reflects geopolitical uncertainties and sluggish investment in natural resources (UNCTAD, 2018).

This downward trend was due to sluggish FDI flows to four major CIS economies (the Russian Federation, Kazakhstan, Azerbaijan and Ukraine). By contrast, flows from developing economies fell by $6 \%$ to $\$ 381$ billion, while those from transition economies rose by $59 \%$ to $\$ 40$ billion. As a result, flows declined, especially to the Russian Federation (by 32\%, to $\$ 25.3$ billion). Thus, most FDI inflows in Russia come to natural resources sector. A decrease in rates of return is a key contributor to an investment downturn. Global average return on foreign investment is now $6.7 \%$, from $8.1 \%$ in 2012. Return on investment is in decline across all regions, with the sharpest drop in Africa, Latin America and the Caribbean. The lower returns on foreign assets may affect longerterm FDI prospects (Lederman et al. 2013).

Many countries continued policy efforts aimed at attracting FDI. In 2017, 65 countries and economies adopted at least 126 investment policy measures, of which $84 \%$ were favorable to investors. They liberalized entry conditions in a number of industries including transport, energy and manufacturing (UNCTAD, 2018). They also promoted and facilitated investment by simplifying administrative procedures, providing incentives and establishing new special economic zones (SEZs). Recently, an increasing number of countries have taken a more critical stance towards foreign investment. New investment restrictions or regulations in 2017 mainly reflected 


\section{ENTREPRENEURSHIP AND SUSTAINABILITY ISSUES}

ISSN 2345-0282 (online) http://jssidoi.org/jesi/

2020 Volume 8 Number 1 (September)

http://doi.org/10.9770/jesi.2020.8.1(35)

concerns about national security and foreign ownership of land and natural resources. Some countries have heightened scrutiny of foreign takeovers, in particular of strategic assets and technology firms. Several countries are considering tightening investment-screening procedures. Investment treaty making has reached a turning point (Morschett et al. 2015).

The US and Britain control about $30 \%$ of Caspian oil fields and $40 \%$ of natural gas fields and are not complacent. Today, Western companies control over $30 \%$ of oil fields and over $80 \%$ of gas fields in Kazakhstan, and over $35 \%$ of gas fields in Azerbaijan (Inkpen and Moffett ${ }^{2011)}$. An insufficiently effective production strategy that is currently in use in Kazakhstan resulted in the following division of subsoil users:

1. state-owned oil companies develop about 60 fields with residual recoverable reserves of approximately 800 million tons;

2. TNCs develop more than 10 fields with extractable reserves exceeding 1 billion tons (Platts 2017).

Therefore, it is necessary to take into account both positive and negative sides of cross-border penetration. TNCs in a market bring the following benefits to a host country:

- capital inflows and exports increase;

- $\quad$ management and marketing strategies update;

- $\quad$ technologies boost;

- $\quad$ proficiency enhancement and salary increase;

- $\quad$ advanced infrastructure formation (Jovanovic 2015);

- $\quad$ standard of living increase (through provision of goods and services);

- $\quad$ job creation (up to 53 million jobs);

- $\quad$ capital, goods and labor integration (Islam and Nag 2010).

The Kazakhstan's presence in the world market provides an increase in exports and budget receipts. Among drawbacks:

- $\quad$ import dependence, which inhibits development of national processing sectors;

- $\quad$ employment imbalance within a country (Ocampo and Ros 2011);

- $\quad$ strong competition between TNCs and local companies;

- $\quad$ consumption standards imposed by TNCs that stimulate artificial needs;

- $\quad$ uneven development on a global scale (less developed countries lose competitiveness and become a natural-resource base for TNCs);

- $\quad$ TNCs may organize pressure on host government and engage it in confrontation; they may also bribe local politicians and finance conspiracies against the government (Whyte 2015). Aside from the above, host countries are at risk of becoming economically dependent upon TNCs, as they become owners of the main strategic resources and because of this acquire a real opportunity to define politically and economically important directions of national development (Omoteso; Yusuf 2017).

Transnational corporations have a significant development and production potential and control over economic, organizational, technological, and intellectual resources. TNCs utilize tight and sometimes aggressive strategies. This allows them to compete with many countries and even to a certain extent impose own interest upon their economic activities. Thus, one may notice a growth in TNC's influence not only in economic but also in political arena (Romashkin 2016). Individual countries and TNCs may find a common ground if TNCs purposely finance a sphere that is strategically important for these particular countries (e.g., campaigns). Thus, through the past 20 years, a cost of parliamentary elections in Japan grew 70-fold. Final price for presidential and congressional elections rose from $\$ 160$ million in 1976 to $\$ 1$ billion in 1980 and to \$1.6 billion in 1984 (Citizens Against Government Waste 2013).

TNCs often prefer to finance election candidates so that to lead their way to the government or parliament. For example, during the presidency of Ronald Reagan, every fourth member of the government was a multimillionaire 


\section{ENTREPRENEURSHIP AND SUSTAINABILITY ISSUES}

ISSN 2345-0282 (online) http://jssidoi.org/jesi/

2020 Volume 8 Number 1 (September)

http://doi.org/10.9770/jesi.2020.8.1(35)

and many of them were entrusted with government posts in sectors where they had major financial interests prior to designation (Bodley 2015). During the presidency of George W. Bush, key politics and the president himself were previously engaged in large oil business. For example, the US Secretary of State Condoleezza Rice was the Director of the Chevron Corporation (the corporation even named one of its largest oil tankers in her honor). The US Vice President Dick Cheney served as Chairman of the Board and Chief Executive Officer of Halliburton, leading provider of oil field services in the Caspian (Pilisuk and Rountree 2015).

From the perspective of raw material security, of interest might be experience of US and Canada. They made the tax system stimulate small state-owned oil companies that together are capable of producing 30 to $40 \%$ of oil on economically acceptable competitive terms (Isser 2016; Begichev et al. 2019). However, capital of national companies should not be excessively increased, as it results in reduced control over their activities and reduced transparency. Instead of financing one or two monopolists, it is better to channel budget allocations to many small state-owned companies so that they could develop and improve production quality. It is also necessary to create an environment in which private companies could grow into TNCs, as any developed country owes its economic growth firstly to TNCs and only then to small and medium-sized businesses. Best experience shows that national capital will gain an opportunity to act as a competitive force if a country houses large transnational companies and a government supports and regulates them in an effective way (Pape 2012).

At present, a strategically important task of Kazakhstan is to re-focus from raw materials. Thus, the President of Kazakhstan has repeatedly instructed government to take control over attraction of TNCs to a processing sector. In his speech, he emphasized the important role of companies like Kazakh Invest and Kazakh Export (Nazarbayev at the enlarged session 2018).

So far, first steps towards this goal have been made. Therefore, non-petroleum sectors already house several large TNCs, including LG Electronics, Coca-Cola, Volkswagen Group, Knauf, Samsung Electronics, Mittal Steel, etc. In fact, a few corporations generate effective demand in real sector of economy. They are mainly large exporters of fuels and raw materials (e.g. KazakhOil, KazTransOil, Hurricane Kumkol Munai, Shymkentnefteorgsintez, the Kazakhstan Electricity Grid Operating Company, Ispat-Karmet, Kazakhmys Corporation, Kazzinc, Kazakhstan Aluminum, and Ust Kamenogorsk Titanium and Magnesium Plant). Financial sector produced two of national "champions" among corporate structures - Kazkommertsbank (sells securities, Eurobonds and GDR shares, in stock markets of Europe and Asia) and Halyk Savings Bank of Kazakhstan (accumulates two-thirds of retail deposits) (Lyutova and Suleymanova 2018). Country was engaged in cooperation with Basel to build a gas chemical facility. General Electric is planning to assemble locomotives inside the country and Samsung began production of sulfur concrete. Heaven House produces household and office furniture, while Skoda has a running car assembling plant. Kazakhstan plans to cooperate with Pilkington and Steinert to establish glass production in the country. There are also preparations made to launch a range of projects with HeidelbergCement AG and Cement Franze/Ital Cement (Litvintseva 2018).

Non-petroleum sector holds about 50\% of FDI inflow and this positive trend remains to date. In 5 months in 2018, the Republic of Kazakhstan signed agreements on implementation of 69 new projects with major investors, including 10 TNCs from China, Turkey, the United States, the United Arab Emirates, the United Kingdom, the EU and other countries (Kazakhstan - the country for doing business 2018). As the President of Kazakhstan notes in his speech at the third Kazakhstan Investment Forum, inputs into the budget of Kazakhstan come from not just petroleum sector, as it is genuinely assumed. In fact, FDI inflow to this sector is below $25 \%$ and the main moneyearners are mining industry, metal industry, ferrochrome production and exports (Rodriguez 2010).

Experience of developed oil exporting countries shows the need for developing an appropriate economic and political strategy. Selling shares on foreign stock exchanges is considered one way to boost national economy, but it also poses a threat of losing economic independence. Existing world order is now about to be remade and countries are expected to pass their roles of main players on to leading transnational corporations (Bulatov, 2016). 


\section{ENTREPRENEURSHIP AND SUSTAINABILITY ISSUES}

ISSN 2345-0282 (online) http://jssidoi.org/jesi/

2020 Volume 8 Number 1 (September)

http://doi.org/10.9770/jesi.2020.8.1(35)

Therefore, it is advisable to search for new ways of mutually beneficial cooperation with TNCs to integrate Kazakhstan into the world economy.Thus, forming transnational corporations for capital increase is an appropriate and economically sound solution. However, it should be ensured that FDI flows do not make a host country economically dependent, as the history knows such cases (Alheet 2019).

To date, world-class corporations are not to be found in Kazakhstan, although the country makes specific steps in this direction. Most Kazakh corporations have low nominal capitals and hold shares, total value of which does not meet minimum requirements for global competition (market capitalization is below $\$ 1$ billion) (Thomsett 2014). With that, refocusing large domestic corporations and enterprises towards transnational is one of main prerequisites for effective market presence.

According to Russian experts, the majority of Russian industrial enterprises have an outdated structure and operate in the context of financial uncertainty. Foreign investors are not accustomed to conducting business with such enterprises because climate of financial uncertainty restricts their financial instruments (Yakupov, 2013). They will not cooperate also due to a high risk of not fulfilling assumed obligations or fulfilling them improperly. It is also worth noting that in some cases, it is far profitable to establish a new enterprise than to reanimate the old one. These cases involve tax arrears, arrearage of wages, loan debts, outdated equipment, low-skilled personnel, and many other problems that require investing. For a long time, this scenario has been the most likely one but a situation takes a turn for better - newly equipped enterprises appear and business interconnections are being made with foreign partners. Generally, a domestic investor creates a positive model of long-term, productive and mutually beneficial cooperation. Under such conditions, foreign investors are given new opportunities, while domestic investors may face new risks (e.g., less competitive investors may be easily absorbed or otherwise outcompeted by foreign investors). These prospects are true for TNCs, which can be in a competitive relationship only with other TNCs, and other market participants should not even bother engaging in it.

TNCs come in their strategic standing and reach corporate goal not only through mergers and acquisitions (M\&A) but also through special inter-firm agreements called strategic alliances (Van Geenhuizen and Nijkamp, 2012). In the market, M\&A between companies occur on a constant basis, but in recent years, they acquire a form of strategic alliances.

Significant cross-border M\&A deals of recent years are:

- $\quad$ British company Vodafone joined forces with American company AirTouch Communications in 1999 in a deal worth $\$ 60$ billion;

- $\quad$ Vodafone AirTouch and the German company Mannesmann reached a \$203 billion merger in 2000;

- $\quad$ France Telecom won the UK based mobile company Orange in 2000 in a deal worth \$46 billion;

- $\quad$ Deutsche Telecom bought the American corporation VoiceStream Wireless Corp. for \$29 billion in 2001

(Nolan 2014).

The world's top telecommunication companies include companies from the US, the UK, Germany and France. Companies in Hong Kong also take an active part in cross-border mergers and acquisitions, unlike Japanese companies, which are rather slow to engage. For example, NTT Docomo Inc., predominant mobile phone operator in Japan, won 15\% stake in KPN Mobile (Netherlands). This recent acquisition can be considered a strategic alliance to split expenses for creation of third-generation (3G) mobile services (Khosrow-Pour 2008).

Cross-border M\&A increasingly occur in the field of Internet services because companies are interested in expanding the range of services provided to mobile users, including e-mail services, etc., and thus, attract more consumers. This sphere of IT\&T (information technology and telecom) is rapidly developing on a global scale, but major M\&A occur only in developed countries, barring some cases when similar processes start in developing countries (China, India, Singapore, Turkey, and Mexico). In this regard, petroleum companies of the Russian 


\section{ENTREPRENEURSHIP AND SUSTAINABILITY ISSUES}

ISSN 2345-0282 (online) http://jssidoi.org/jesi/

2020 Volume 8 Number 1 (September)

http://doi.org/10.9770/jesi.2020.8.1(35)

Federation have the greatest potential due to a significant amount of resources in their hands, which allows them to compete with world leaders in this industry, sell raw materials and permit an extraction operations in the company-controlled area. Besides, many global TNCs have divisions in the Russian Federation (Nosova and Ronshina 2017).

Strategic alliances involve the latest software developers and manufacturers of communication devices, in particular, Microsoft (USA), Motorola (USA), Psion (Great Britain), Nokia (Finland), Ericsson (Sweden), and Sony (Japan). Between 1992 and 1996, several strategic alliances were established between leading transnational corporations in telecommunication sector. Telecommunications companies in Sweden, the Netherlands and Switzerland ventured together in the first alliance Unisource. Subsequently, Unisource united with the WorldPartners alliance, which had 25 members at the time (Robinson, 2014). The third telecommunication alliance is known as the Concert Communications. The latter was formed as a joint venture of British Telecom and MCI Communications. By 1998, it had grown to 50 participants. In 1996, the Global One alliance was created and included Sprint, France Telecom and Deutsche Telecom. In the late 90s, these strategic alliances split up. For example, British Telecom began to cooperate with AT\&T; WorldPartners almost ceased to exist; Global One had financial problems; and German and French partners had disagreements regarding Deutsche Telecom/Telecom Italia venture (Welfens et al. 2012).

The major difference between M\&A and strategic alliances formed in the host country is the form of control. Cross-border M\&A provide almost unlimited control in a certain segment of economy and push aside undesirable competitors in the market. A strategic alliance is more flexible when it comes to influencing the economy of a host country within a framework of business cooperation between economic entities. Its main advantage is a redistribution of risks between members, whereas a disadvantage is that all members are co-dependent and their efforts must be well coordinated (otherwise, losses are inevitable). In turn, M\&A allow benefiting from market dominance but require long-term planning, as they need extensive amounts of financial resources and time to cover initial costs.

Despite a rather significant FDI inflow, there are not enough cross-border M\&A in Kazakhstan. Generally, crossborder M\&A deals involve purchase and sale agreements. Between 2002 and 2004, total sales amounted to $\$ 936$ million (5.8\% in CIS countries and 52\% in Russia), while total purchases were $\$ 170$ million (1.6\% in CIS countries and 97\% in Russia). However, M\&A market in the Russian Federation may feel the influence of the US sanctions (Sharipov, 2012). With that, judicial practice shows that TNCs have a significant and not necessary positive impact on the economy of Kazakhstan. Thus, the Commercial Court judge of the Republic of Kazakhstan brought on a case concerning a suit of the Deputy Prosecutor General representing a list of companies vs. TransWorld Group. The claim was to invalid sale and purchase contracts and credit agreements. The companies involved in the case are the Aluminum of Kazakhstan OJSC, the Sokolovsko-Sarbaysky Mining and Production Association, the Aksu Ferroalloys Plant (the branch of Kazchrome Transnational Company), the Ferrochrome OJSC, and the Don Mining and Enrichment Plant. The case was settled on January 27, 1999 (Case No. 809-37-7) (Didenko 1999).

The Court found unproven planned "enslavement" of Kazakhstan enterprises by individual companies in the list of defendants. Among them, Trans-World Group PLC, Trans-World Metals International Limited, Trans-World SA, Trans-World (UK) Ltd, Trans-World (Allous) Limited, Indalo Trading Company Ltd, Global Enterprises Limited, Japan Chrome SA, Krasalao Limited, Neep, Trans-World Land Co. Limited, Eurasian Aluminum Consortium, Alkos Investment Syndicate S.A., Allied Intertrade S.A., Euro Utilities S.A., Transmetal Limited, Nippon Chrome Corp. The Court did not foreclose belonging of listed companies to TWG but pursuers did not prove these companies' direct participation in causing damage through a conclusion of unconscionable contracts, ineffective management, and actions that violate interests of Kazakhstan enterprises. Therefore, these defendants were delisted. 


\section{ENTREPRENEURSHIP AND SUSTAINABILITY ISSUES}

ISSN 2345-0282 (online) http://jssidoi.org/jesi/ 2020 Volume 8 Number 1 (September) http://doi.org/10.9770/jesi.2020.8.1(35)

Thus, the judicial decision concerning the Trans-World Group was to not recognize the TNC as an independent participant. Table 1 presents the final list of management companies, banks and traders that amounted to defense.

Table 1. Final list of management companies, banks and traders

\begin{tabular}{|c|c|}
\hline Defendant & Address \\
\hline Tykaz Chrome Corporation & $\begin{array}{l}\text { Panm Chambers 3, P.O. Box 3152, Road Town, Tortola, } \\
\text { British Virgin Islands }\end{array}$ \\
\hline Landal S.A.M. & $\begin{array}{l}\text { Les Acanthes, 6, Avenue des Citronniers, Monte Carlo, } \\
98000 \text { Monaco }\end{array}$ \\
\hline Japan Chrome Corporation & $\begin{array}{l}\text { Panm Chambers 3, P.O. Box 3152, Road Town, Tortola, } \\
\text { British Virgin Islands }\end{array}$ \\
\hline Whiteswan Worldwide Limited & $\begin{array}{l}\text { Panm Chambers 3, P.O. Box 3152, Road Town, Tortola, } \\
\text { British Virgin Islands }\end{array}$ \\
\hline Ivedon International Limited & $\begin{array}{l}\text { Panm Chambers 3, P.O. Box 3152, Road Town, Tortola, } \\
\text { British Virgin Islands }\end{array}$ \\
\hline United Global Bank Limited & $\begin{array}{l}\text { Les Acanthes, 6, Avenue des Citronniers, Monte Carlo, } \\
98000 \text { Monaco }\end{array}$ \\
\hline Zalogobank CJSB & $\begin{array}{l}\text { Pogodinskaya Street 24, building 1, Moscow, Russian } \\
\text { Federation }\end{array}$ \\
\hline Eurasian Aluminum Consortium & $\begin{array}{l}94 \text { Dowdeswell Street, P.O. Box 7521, Nassau, Bahamas; } \\
\text { P.O. Box 659, Road Town, Tortola, British Virgin Islands }\end{array}$ \\
\hline Transmetal Management Limited & $\begin{array}{l}\text { Panm Chambers 3, P.O. Box 3152, Road Town, Tortola, } \\
\text { British Virgin Islands }\end{array}$ \\
\hline Minamet Investments Corp. & Cumberland Street, P.O. Box 529 Nassau, Bahamas \\
\hline Whiteswan Limited & 25 Harley Street, London W1N 2BR, England \\
\hline Metallurg JSC & $\begin{array}{l}12 \text { Bryanskaya Street, Moscow, } 121059 \text { Russian } \\
\text { Federation }\end{array}$ \\
\hline VIZEL LLC & $\begin{array}{l}\text { Room 505, build. 249, Lenina Street, Elista, Russian } \\
\text { Federation }\end{array}$ \\
\hline $\begin{array}{l}\text { Trans-World Metals International } \\
\text { Limited }\end{array}$ & $\begin{array}{l}\text { Panm Chambers 3, P.O. Box 3152, Road Town, Tortola, } \\
\text { British Virgin Islands }\end{array}$ \\
\hline Base Metal Trading Ltd. & Genesis Building, P.O. Box 813, Grand Cayman \\
\hline General Products Inc. & $\begin{array}{l}\text { Les Acanthes, 6, Avenue des Citronniers, Monte Carlo, } \\
98000 \text { Monaco; } \\
\text { Panm Chambers 3, P.O. Box 3152, Road Town, Tortola, } \\
\text { British Virgin Islands }\end{array}$ \\
\hline Mineral Trading Resources Corp. & 94 Dowdeswell Street, P.O. Box 7521, Nassau, Bahamas \\
\hline Intermetal Group Ltd. & $\begin{array}{l}\text { International Building, Wickhams Cay, Road Town, } \\
\text { Tortola, British Virgin Islands }\end{array}$ \\
\hline Swiss Aluminium Consortium & $\begin{array}{l}\text { Panm Chambers 3, P.O. Box 3152, Road Town, Tortola, } \\
\text { British Virgin Islands }\end{array}$ \\
\hline Tradalco Ltd & 14-15 Parliament Street, Dublin 2, Republic of Ireland \\
\hline Alastro Management Corporation & $\begin{array}{l}\text { Postfech 583, Aeulestrasse 38, FL-9490, Vaduz, } \\
\text { Liechtenstein }\end{array}$ \\
\hline Westdean Metals Inc. & Genesis Building, P.O. Box 813, Grand Cayman \\
\hline
\end{tabular}

Individual trade contracts and credit agreements were found to be invalid due to unfair and unacceptable terms. Documents imposed unprecedented terms of payment (180 days), as well as unfavorable loan conditions and precluded opportunity to search for and select best buyers and banks. The Court found these conditions to be artificially created and forcing Kazakhstan enterprises to enter into oppressive contracts (Didenko 1999). According to the Court, credit agreements were made to screen actual sale-purchase deals by changing a system and the amount of payment taken as a settlement in the form of a loan (Oshionebo 2018). Such actions were 
regarded as a violation of business ethics under the paragraph 2 of the Article 160 of the RK Civil Code. The Court came to a decision that Trans-World Group deprived enterprises of their freedom of business action, forcing them to enter into contracts with its companies on unfavorable conditions, thereby creating unfair competition and violating requirements of business ethics. According to paragraph 2 of Article 159 of the RK Civil Code, this is a good reason for an invalidation of transactions.

Thus, defendants were obligated to pay (Figure 2):

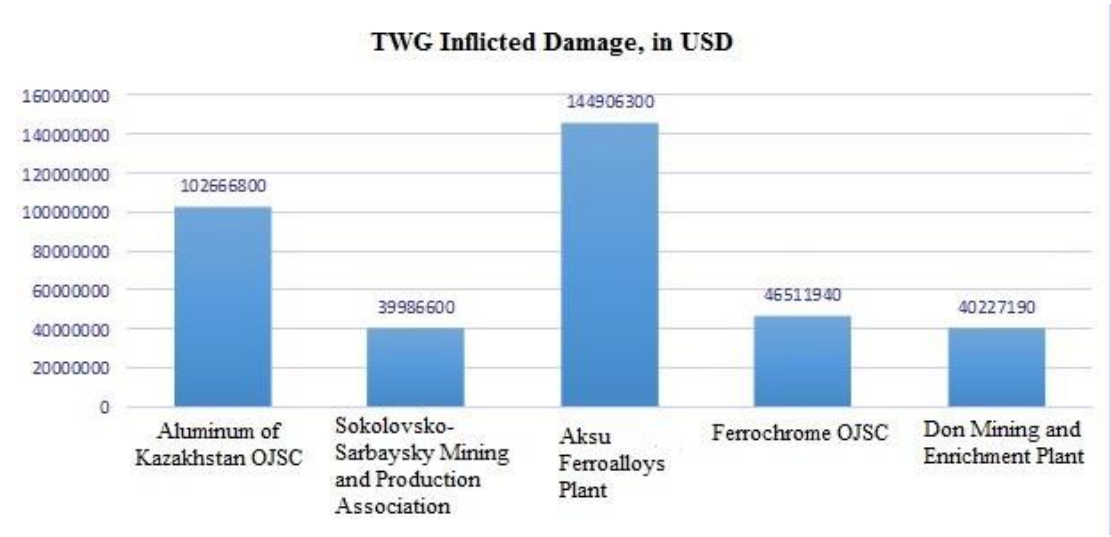

Figure 2. TWG Inflicted damage, in USD

Aluminum of Kazakhstan, OJSC:

the damage of $\$ 102.666 .800$. Restitution covered a debt under credits allocated by UGB (\$13.262.000) and Zalogobank (\$9.041.000) and compensation was $\$ 80.363 .800$;

Sokolovsko-Sarbaysky Mining and Production Association:

the damage of \$39.986.600. Restitution amount included \$24.927.000 in compensation for credit debt and \$15.059.600 in compensation for damage.

Aksu Ferroalloys Plant:

the damage of $\$ 144.906 .300$. Restitution amount covered debts owed to UGB (\$56.561.000) and Zalogobank (\$14.319.000) and compensation for damage was $\$ 55.426 .300$.

Ferrochrome OJSC:

the damage of $\$ 46.511 .940$. Restitution covered a $\$ 33.818 .000$ debt and the company received additional $\$ 12693940$ in compensation.

Don Mining and Enrichment Plant: the damage of $\$ 40.227 .190$. Restitution covered a debt under credits allocated by UGB (\$14.325.000) and compensation was \$25.902.190 (Picciotto 2018). This decision of the Commercial Court is one of the few that has been subjected to a thorough analysis by scientists in Kazakhstan. The case is most indicative of mistakes and a lack of professionalism among state authorities that failed to select suitable partners for Kazakhstan enterprises, to conclude beneficial contracts, to articulate conditions for early termination, and to ensure proper management. Prosecutor's office and the court attempted to repair what was damaged by following the sense of justice and the black letter law. While Kazakhstan enterprises were making efforts towards justice, their foreign partners were more interested in their own benefit from this relationship. The emerged conflict proves an imperfection of Kazakhstan legislation. Despite struggles that TNCs have in Kazakhstan, global situation is somewhat favorable. In the climate of crisis and market narrowing, investors are forced to look for candidates for capital injection. FDI deals are rather successful than unsuccessful (Basin and Greshnikov 2003). However, Kazakhstan and Russia fail to secure mutual benefit of participants in investment relationship, as well as national interests. Foreign investors professionally utilize all the gaps and weaknesses that can be found in the investment law (Aristova 2018). In this regard, TNCs are the most prepared, as they have substantial resources to create favorable conditions for market presence. 


\section{ENTREPRENEURSHIP AND SUSTAINABILITY ISSUES}

ISSN 2345-0282 (online) http://jssidoi.org/jesi/ 2020 Volume 8 Number 1 (September)

http://doi.org/10.9770/jesi.2020.8.1(35)

\section{Conclusions}

Transnational corporations and their business activities should be provided with a legislative framework. For this purpose, a special act - the Law on Foreign Investment Regulation in Strategic Sectors of Economy - is required. The document should have a separate section specifically devoted to a regulation of cross-border mergers and acquisitions in strategic sectors of the economy. Crucial aspects that need special legal regulation involve core principles of cross-border mergers and acquisitions; entities engaged in cross-border mergers and acquisitions, their rights and obligations; guarantees provided to participants in cross-border mergers and acquisitions; and the government control in the field of cross-border mergers and acquisitions.

\section{Study Limitations}

Since the conducted analysis is retrospective, recommendations and forecasts are valid and have high implementation value only in those economic and legal conditions that are discussed in the study (namely, in Russia and Kazakhstan).

\section{References}

2016 Global R\&D Funding Forecast. 2016. Retrieved from http://www.iriweb.org/sites/default/files/2016GlobalRDFundingForecast.pdf

Alheet, A. F. 2019. Investigating the relationship between entrepreneurial activity and economic growth: a case of Middle East. Entrepreneurship and sustainability issues, 7(2), 1036-1047. https://doi.org/10.9770/jesi.2019.7.2(17)

Aristova, E. 2018. Tort litigation against transnational corporations in the English courts: The challenge of jurisdiction. Utrecht L. Rev., 14,6 .

Basin, Y.G.; Greshnikov, I.P. 2006. Selected works on civil law. Collection of scientific works, St. Petersburg: Legal Center-Press, 591.

Berberoglu, B. 2016. The Global Capitalist Crisis and Its Aftermath: The Causes and Consequences of the Great, Ashgate Publishing, Ltd, 360.

Begichev A.V.; Galushkin A.A.; Zvonarev A.A.; Shestak V.A. 2019. History of the creation and activities of the League of Nations. Voprosy Istorii, 9, 108-113. (In Russian)

Bodley, J. 2015. The Power of Scale: A Global History Approach: A Global History Approach, Routledge, 296.

Bulatov, A.S. 2016. World Economy and International Economic Relations: A complete book for bachelors, Tbilisi - PH "UNIVERSAL", 632-654 (in Russian)

Citizens Against Government Waste. 2013. The Pig Book: How Government Wastes Your Money, Thomas Dunne Books; First edition, 208.

Civil Code of the Republic of Kazakhstan. 1994. Enforced by the Decree of the Supreme Council of the Republic of Kazakhstan.

Didenko, A.G. 1999. Decision of the Supreme Court of the Republic of Kazakhstan, Civil law. Articles. Comments Practice. Almaty.

Henderson, J.W. 2014. Health Economics and Policy, Cengage Learning; 6 edition, 280-302.

Inkpen, A.C.; Moffett, M.H. 2011. The Global Oil \& Gas Industry: Management, Strategy \& Finance, PennWell Books, 581.

Islam, M.; Nag, N.C. 2010. Economic Integration in South Asia: Issues and Pathways, Pearson Education India, 297.

Isser, S. 2016. The Economics and Politics of the United States Oil Industry, 1920-1990: Profits, Populism and Petroleum, Routledge, 486.

Jones, J.; Wren, C. 2016. Foreign direct investment and the regional economy, Routledge, 5-11. 


\section{ENTREPRENEURSHIP AND SUSTAINABILITY ISSUES}

ISSN 2345-0282 (online) http://jssidoi.org/jesi/ 2020 Volume 8 Number 1 (September)

http://doi.org/10.9770/jesi.2020.8.1(35)

Jovanovic, M.N. 2015. The Economics of International Integration, Second Edition, Edward Elgar Publishing, 720.

Kazakhstan - the country for doing business (2018). Retrieved from https://www.zakon.kz/4926451-vystuplenie-premer-ministra-rk$\underline{\text { na.html }}$

Khasbulatov, R.I. 2015. International entrepreneurship: A textbook. 2nd Edition, Prospect Publishing House, 437.

Khosrow-Pour, M. 2008. Encyclopedia of Information Science and Technology, Second Edition, Information Resources Management Association, USA, 5266.

Kordos, M.; Vojtovic, S. 2016. Transnational corporations in the global world economic environment, Procedia-Social Behav. Sci. 230: 150-158. https://doi.org/10.1016/j.sbspro.2016.09.019

Lederman, D.; Messina, J.; Pienknagura, S.; Rigolini, J. 2016. Latin American entrepreneurs: Many firms but little innovation, The World Bank, 168.

Litvintseva, G. 2018. Economic Development of the Eurasian Integration Countries, Novosibirsk: NGTU, 24-51. (in Russian)

Lyutova, N.L.; Suleymanova, F.O. 2018. Labor law and social security law: history and forecast, Proceedings of the International Scientific and Practical Conference, Prospect Publishing House, 412-425. (in Russian)

Matsuzawa, S. 2019. Activating China: Local Actors, Foreign Influence, and State Response, Routledge, 192.

Morschett, D.; Schramm-Klein, H.; Zentes, J. 2015. International Research \& Development, In Strategic International Management, Springer Gabler, Wiesbaden, 453-476.

Motohashi, K. 2015. Global Business Strategy: Multinational Corporations Venturing into Emerging Markets, Springer Texts in Business and Economics, 259.

Mudacumura, G.M.; Mebratu, D.; Haque, M. 2017. Sustainable Development Policy and Administration, Routledge, 716.

Nazarbayev N., speech at the enlarged session of the government of the Republic of Kazakhstan. 2018. Retrieved from https://www.zakon.kz/4903109-o-chem-govoril-nazarbaev-na.html

Nolan, P. 2014. Chinese Firms, Global Firms: Industrial Policy in the Age of Globalization, Routledge, 176.

Nosova, N.; Ronshina, N. 2017. International economic relations, Scientific book, 127-134.

Nukusheva, A.A.; Kudryavtseva, L.V. 2017. Civil-legal status of a foreign legal entity in Private International Law: a comparative legal analysis, Karaganda Univ. Bull., Law Ser. 4(88).

Ocampo, J.A.; Ros, J. 2011. The Oxford Handbook of Latin American Economics, Oxford University Press, 932.

Omoteso, K.; Yusuf, H. 2017. Accountability of transnational corporations in the developing world. Critical perspectives on international business, 13(1), 54-71.

Oshionebo, E. 2018. Corporations and nations: power imbalance in the extractive sector. American Journal of Economics and Sociology, 77(2), 419-446.

Pape, W. 2012. East Asia 2000 and Beyond: Shaping Factors/Shaping Actors, Routledge, 220.

Perrone, N. M. 2018. UNCTAD’s World Investment Reports 1991-2015: 25 Years of Narratives Justifying and Balancing Foreign Investor Rights. The Journal of World Investment \& Trade, 19(1), 7-40.

Picciotto, S. 2018. International tax, regulatory arbitrage and the growth of transnational corporations. Transnational Corporations, 25(3), 27-53.

Pilisuk, M.; Rountree, J.A. 2015. The Hidden Structure of Violence: Who Benefits from Global Violence and War, NYU Press, 304. 


\section{ENTREPRENEURSHIP AND SUSTAINABILITY ISSUES}

ISSN 2345-0282 (online) http://jssidoi.org/jesi/ 2020 Volume 8 Number 1 (September)

http://doi.org/10.9770/jesi.2020.8.1(35)

Platts. 2017. Methodology and Specifications Guide: Crude Oil, S\&P Global, 32.

Preston, L.E.; Windsor, D. 2013. The rules of the game in the global economy: Policy regimes for international business, Springer Science \& Business Media, 294.

Robinson, W.I. 2014. Global Capitalism and the Crisis of Humanity, New York: Cambridge University Press, 246.

Rodriguez, A.M. 2010. The newest history of Asian and African countries: XX century (1945-2000). Part 2, Moscow: Vlados, 463.

Romashkin, T.V. 2016. TNCs: formation and development in the context of globalization, Saratov: Nauka Publishing Center LLC, 160.

Sacher, W.; Cooney, P. 2018. Environmental Impacts of Transnational Corporations in the Global South, Emerald Group Publishing, 134 $-147$.

Sagafi-Nejad, T.; Belfield, R. 2014. Transnational corporations, technology transfer and development: A bibliographic sourcebook, Elsevier.

Sharipov, T.F. 2012. Macroeconomic planning and forecasting of the national economy, Orenburg: OGU, 312.

Stopford, J.M. 2011. Directory of Multinationals: The World's Largest Global Enterprises, London: Waterlow, 1702.

Tauris, I.B. 2011. Arab cultural studies, Mapping the Field, 124.

Thomsett, M.C. 2014. Getting Started in Stock Analysis, Illustrated Edition. Wiley, 384.

Tomasic, R. 2017. Research Handbook on Transnational Corporations, Edward Elgar Publishing, 375-384.

UNCTAD. 2018. World Investment Report. Retrieved from https://unctad.org/en/pages/PressRelease.aspx?OriginalVersionID=464

United Nations Conference on Trade and Development. 2011. Non-equity Modes of International Production and Development, 226

Van Geenhuizen, M.; Nijkamp, P. 2012. Creative Knowledge Cities: Myths, Visions and Realities, Edward Elgar Publishing, 320.

Welfens, P.J.J.; Yarrow, G.; Grinberg, R.; Graack, C. 2012. Towards Competition in Network Industries: Telecommunications, Energy and Transportation in Europe and Russia, Springer, 570.

Whyte, D. 2015. How Corrupt is Britain? London: Pluto Press, 198.

Yakupov, Z.S. 2013. Major aspects of economics, management and law, An international scientific conference summary, 56-59 (in Russian).

Aigul NUKUSHEVA is the PhD of law and Associate Professor at Department of Civil and Labour Law, Buketov Karaganda State University (Kazakhstan).

ORCID ID: 0000-0002-6451-4751

Gulzhazira ILYASSOVA is the PhD of law and Associate Professor at Department of Civil and Labour Law, Buketov Karaganda State University (Kazakhstan).

ORCID ID: 0000-0002-0926-0154

Larisa KUDRYAVTSEVA is the PhD of law and Associate Professor, Chair of International Private and Business Law, FGBOU VO "Kuban State Agrarian University named after I.T. Trubilina" (Russian Federation).

ORCID ID: 0000-0002-9301-238X 


\section{ENTREPRENEURSHIP AND SUSTAINABILITY ISSUES}

ISSN 2345-0282 (online) http://jssidoi.org/jesi/ 2020 Volume 8 Number 1 (September) http://doi.org/10.9770/jesi.2020.8.1(35)

Zhanna SHAYAKHMETOVA is the PhD of law and Associate Professor at Department of criminal law disciplines, Atyrau State University after Kh. Dosmukhamedov (Kazakhstan).

ORCID ID: 0000-0001-6965-9813

Amina JANTASSOVA is Master of Laws and Seniour teacher, Chair of legal regulation, Karaganda economic university Kazpotrebsouyz (Kazakhstan).

ORCID ID: 0000-0003-0394-5061

Larisa POPOVA is the PhD of law and Associate Professor at Department of civil law, FGBOU VO "Kuban State Agrarian University named after I.T. Trubilina" (Russian Federation).

ORCID ID: 0000-0002-9421-3095

Make your research more visible, join the Twitter account of ENTREPRENEURSHIP AND SUSTAINABILITY ISSUES:

@Entrepr69728810

Copyright (C) 2020 by author(s) and VsI Entrepreneurship and Sustainability Center

This work is licensed under the Creative Commons Attribution International License (CC BY).

http://creativecommons.org/licenses/by/4.0/

cC) (i) Open Access 